\title{
EQUiLIBRIUM
}

Quarterly Journal of Economics and Economic Policy

2016 VOLUME 11 ISSUE 3, September

p-ISSN 1689-765X, e-ISSN 2353-3293

www.economic-policy.pl

Ciburiene, J. (2016). The Evaluation of Economic Development Index of Poland and Lithuania in the Context of the European Union. Equilibrium. Quarterly Journal of Economics and Economic Policy, 11(3), 437-449. DOI: http://dx.doi.org/10.12775/EQUIL.2016.020

Jadvyga Ciburiene*

Kaunas University of Technology, Lithuania

\section{The Evaluation of Economic Development Index of Poland and Lithuania in the Context of the European Union}

JEL Classification: $O 10 ; O 11 ; F 63$

Keywords: Lithuania; Poland; economic development; economic development index; macroeconomic indicators; regional development

\begin{abstract}
The purpose of this research is to characterize and evaluate the results of economic development of Poland and Lithuania. In order to analyze the changes of economic development, the index of economic development as share of sustainable development is used. Empirical analysis for the years 2005-2012 is conducted. As a result of the research - the country's main macroeconomic development indicators are unified in order to create a development index.
\end{abstract}

\section{Introduction}

Lithuania and Poland, as neighboring countries, present satisfactory cases of their economic development. The historical, economical, political and cultural development of Lithuania and Poland shares some similarities, but also shows differences. When comparing the economical development of these countries and determining the advantages of each country, it would be

(C) Copyright Institute of Economic Research

Date of submission: March 14, 2015; date of acceptance: February 25, 2016

* Contact: jadvyga.ciburiene@ktu.lt, Kaunas University of Technology, School of Economics and Business, Department of Economics, Donelaicio str. 20-501, Kaunas, Lithuania 
appropriate to analyze their economical policies. In 2004 Lithuania and Poland joined the European Union (together with other 9 Central and Eastern Europe countries). Membership in the EU is an important factor for the cohesion of these countries' economies. Motivation for writing the paper is the situation when many indicators are used when describing economic development of the individual country. A number of economic bodies of research (Krugman \& Wells, 2006; Blanchard \& Hoarau, 2011) describe economic development measurement possibilities. Scientific research show that some indicators which are used when seeking to determine the status of the country's development exist. For this reason, the most significant economic indicators, such as gross domestic product (GDP), GDP per capita (GDPpc), gross national income (GNI), gross national income per capita (GNIpc), genuine progress indicator (GPI), human development index (HDI), foreign direct investment (FDI), expenditure for research and development (R\&D), saving, investment, asset prices, employment, unemployment, inflation interest rate and others indicators or their groups are examined. The opinion that GDP or GDPpc are incomplete to measure economic performance is broadly characterized by eminent economic scientists Stiglitz, Sen and Fitoussi (Commisssion on..., 2009, pp. 1-292). They conclude that the committee does not recommend creating a new super-index which could integrate more economic, social, political, cultural and environmental indicators. The scientists notice that it is best of all to correct shortcomings of GDP, evaluating for example leisure, income inequality.

HDI is created by Sen and Ul Hag in 1990 and fitted in United Nations Development Programme (Ul Hag, 1995, pp. 1-288). This determines annual evaluations of HDI for each country as members' of the United Nations Organization. The HDI expresses the basic elements of human development (healthy and long life index, adult literacy rate index and standard of living as GDPpc at purchasing power parity (PPP) terms in US dollars), but it does not give full results of economic development (Selim, 2015, pp. 1-2). The discussions about the possibility to use HDI for the human development comparison between countries enlarges and this indicator was renewed from the year 2010, clarifying firstly, education index and, secondly, the standard of living calculating as GNIpc at purchasing power parity (PPP) terms in US dollars. The analysis of scientific literature (Radovanovic, 2011, pp. 193-208) shows that human development is broader than HDI. Due to this reason, the level of the country development is described best by the combination of different indicators. Moreover, HDI is criticized for the lack of technological development changes values in it (Wolff et al., 2011, pp. 843-870). 
Another indicator - Self-Organizing Maps (SOM) is based on the HDI components. Rende and Donduran (2011, pp. 989-1003) SOMs are characterized as exclusive type of the countries grouped into the clusters, according to their similarities in their development. SOMs creates favorable conditions to analyze the results of neighbor countries clusters development, its causes, and the applied economical policies. In this case, human development is based on the precondition of the possibility to choose economic policy from the adopted potential neighborhoods in the same cluster. Such behavior of the government institutions of separate countries can help to improve and to increase the structural elements of the index and the total amount of them, by calculating SOM.

In the scientific literature, the effects of international trade on quality of life and economical development are discussed. Besides the evaluation that the quality of life is deteriorating due to international trade, some authors (Davies \& Quinlivan, 2006, pp. 868-876) positively evaluate the increase of international trade, international competitiveness, economic development, which lead to the increase of employment level and social welfare.

The point of this article is to show the results of economical development and happening structural changes in Lithuania and Poland in the period of 2005-2012. The analyzed period includes the period before the 20072008 global financial crisis, the period of the crisis. The economical development results are analyzed in the article by comparing main macroeconomic indexes. Basing on those indexes, Lithuania and Poland are given an economic development index. The analysis described in this paper is based on World Bank data statistics, the Statistical Office of Lithuania and the Central Statistical Office of Poland. The point of this article - to analyze a country's main macroeconomic development indexes, characterizes economic development indexes and unifies them creating an economical development index. The goals of the article: to analyze and compare Lithuania's and Poland's main macroeconomic development indexes; to describe indexes that are used to evaluate a country's economical development and create an economical development index and characterize its change in the period of 2005-2012 in the context of the European Union Member States (EU). The research shows the changes of economic development indicators in Lithuania and Poland, seeking cohesion with the EU economic development the level in average and in the perspective - to align to the counties' higher economic development level. 


\section{Research Method}

A number of economic research describe different economic development measurement possibilities. Due to this reason, it is important to determine and to evaluate the changes of economic development and structure changes using the index of economic development of Lithuania and to compare it with the economic development index of the neighboring country and international cooperation partner from the West - Poland and the EU-28. It is important to characterize the similarities and the main diversities of the economic development factors and structural changes in the years 2005 -2013 in Lithuania and Poland. The structural changes of the country economy are based on the significance of the main economic activities (such as agriculture, industry and services) over time (Dudzevičiūtè, 2013, pp.1323). These economic activities can be measured by their share of value added and employment (Miškinis et. al., 2013, pp.15-28).

One of the methods most commonly used for the analysis of economic development is the evaluation of main macroeconomic indicators and their changes. In order to describe the changes of economic development, the economic development index as part of sustainable development in these countries was count up, also absolute and relative values are given in parallel. The method of the base indexes comparison is applied, whereas the first year of the analyses period is chosen as base year.

The priorities of economic development in Lithuania and Poland are based on the European Commission Strategy "A Strategy for Smart, Sustainable and Inclusive Growth" (2010) is significant. The priorities of the Strategy are: smart development, related to the development based on knowledge and innovation development; sustainable development - substantiated on economical use of resources and competitiveness; inclusive growth well-grounded on high level of employment, high level of social cohesion among regions and countries. The measurement of the main economic development indicators and economic policy of government of countries leads to positive structural changes of economic activities and higher results of economic development. The scientific literature gives some alternatives for the evaluation of economics aspects of sustainable development.

Researchers (Krugman \& Wells, 2006, pp. 199-200; Tvaronavičiene \& Kalašinskaite, 2010, pp. 5-19) show that FDI directly affects the economy of the country receiving foreign investment. It is determined (Tvaronavičiene \& Kalašinskaite, 2010, pp. 5-19) that after 5-6 years the effect of these investments begins to decline. It is shown (Ciegis et al., 2010a, p. 19) that one of the most important economic indicators are GNIpc, FDI and unemployment. Even (Ciegis et al., 2010b, pp. 202-207) 
the structure of GDP, created in separate economic activities (agriculture, industry, services), and employment in these activities are analyzed deeper.

This article seeks to compare the economic development between Lithuania and Poland in the context of the EU-28 data such as: GNIpc, foreign direct investment per capita (FDIpc) and employment (E), using World Bank data is analyzed. Basing on the given analysis of the main macroeconomic indicators, it is determined what is achieved in economic development in analyzed countries. Year 2005 was chosen as a base year for the evaluation of the economic development index in Lithuania, Poland and the EU-28 in the period of 2005-2012 (the index of economic development in year 2005 is equal to $100.0 \%$ ). This index of economic development characterizes economic development of country, evaluating the changes of three described macroeconomic indicators: 1) GNIpc based on PPP, 2) FDIpc and 3) E. Due to lack of information, it is problematic to define the share of each economic indicator included in this index so the method of equal base weights is used. While evaluating the economic development, only those indicators are taken into calculation whose increase would have a positive effect on economic development (GNIpc, FDIpc and E) (Ciburiene, 2014, pp. 685-692).

The economic development index $\left(I_{E D V}\right)$ is evaluated according to the (1) Formula:

$$
I_{E D V}=\sum_{i=1}^{n} a i \times I i
$$

where:

$a i-$ is the weight of separate element of economic development indicator; $I i-i s$ the separate element, indicator involved into index of economic development.

The sum of all three weight separate elements (Formula 2) of the economic development indicators is:

$$
\sum_{i=1}^{n} a i=a_{1}+a_{2}+a_{3}=1
$$

Three indicators are used: indicator of GNIpc $\left(I_{G N I p c}\right)$, indicator of FDIpc $\left(I_{F D I p c}\right)$ and indicator of employment $\left(I_{E}\right)$. Three indicators take the weighting expression, described in the (3) Formula: 


$$
I_{E D V}=a_{1} \times I_{G N I p c}+a_{2} \times I_{F D I p c}+a_{3} \times I_{E},
$$

The increase of these indicators means positive effects of economic development; and the decrease of these indicators means negative changes in the economy, related with recession of the economy described.

\section{The Economic Development Indicators}

The growth of real GDPpc or economic growth is the most important indicator of economic development, showing the living standards in the country. The analysis of real GDP growth given in Table 1 shows that real GDP was contracted mostly in the year 2009 , accordingly in Lithuania it diminished by $14.7 \%$, in the EU - by $4.3 \%$ and in the EU euro zone - by $4.4 \%$. The real GDP in Poland, unlike Lithuania, increased during the years 20052012. The key factors of economic development in Lithuania and Poland are based, firstly, on the qualified labour force, which is open to new changes and is learning fast. Secondly, economic development is grounded on the efficiency driven factors (as higher education and training; market efficiency; technological readiness) during the years 2005-2007, and from year 2008 to year 2012 - on the economic development factors based on the transition from the efficiency driven to innovation driven factors. As innovation driven factors are evaluated business sophistication and innovation (Shwab \& Porter, 2006; Shwab, 2013).

The structure of agriculture in the country, which creates added value, is one of the most important factors for economic development. After Lithuania and Poland became members of the EU, the possibility of emigration arose. Due to emigration and low birth rates, the Lithuanian population decreased by $9.9 \%$ during the years 2005-2012 and fell from 3.32 million to 2.99 million. The population of Poland, in opposition to Lithuania, has increased by $1.0 \%$ and has grown from 38.18 million to 38.54 million (or by 380 thousand people). The changes in the number of population in the EU are possitive: the population has increased by $1.9 \%$ (or by 9.24 million) in comparison with the base year 2005. 
Table 1. The main indicators of economy and economic activity in the years 20052012

\begin{tabular}{|c|c|c|c|c|c|c|c|c|}
\hline & 2005 & 2006 & 2007 & 2008 & 2009 & 2010 & 2011 & 2012 \\
\hline \multicolumn{9}{|c|}{ 1. Real GDP growth rate (EG), \% } \\
\hline LT & 7.8 & 7.8 & 9.8 & 2.9 & -14.7 & 1.3 & 6.0 & 3.7 \\
\hline PL & 3.5 & 6.2 & 7.2 & 3.9 & 2.6 & 3.7 & 4.8 & 1.0 \\
\hline EU & 2.1 & 3.3 & 3.2 & 0.3 & -4.3 & 2.1 & 1.8 & -0.4 \\
\hline EUea & 1.7 & 3.3 & 3.0 & 0.4 & -4.4 & 2.1 & 1.7 & -0.7 \\
\hline \multicolumn{9}{|c|}{ 2. Agriculture value added, $\%$ of GDP } \\
\hline LT & 4.8 & 4.3 & 3.9 & 3.7 & 3.4 & 3.5 & 3.8 & 4.0 \\
\hline $\begin{array}{l}\text { - growth } \\
\text { rate, } \%\end{array}$ & 100.0 & 89.6 & 81.2 & 77.1 & 70.8 & 72.9 & 79.2 & 83.3 \\
\hline $\mathrm{PL}$ & 3.3 & 3.1 & 3.4 & 2.9 & 2.9 & 3.0 & 3.3 & 3.2 \\
\hline $\begin{array}{l}\text { - growth } \\
\text { rate, } \%\end{array}$ & 100.0 & 93.4 & 103.0 & 95.7 & 95.7 & 90.9 & 100.0 & 97.0 \\
\hline EU & 1.7 & 1.6 & 1.6 & 1.6 & 1.4 & 1.6 & 1.6 & 1.6 \\
\hline EUea & 1.8 & 1.7 & 1.7 & 1.7 & 1.5 & 1.6 & 1.7 & 1.7 \\
\hline \multicolumn{9}{|c|}{ 3. Industry value added, $\%$ of GDP } \\
\hline LT & 32.9 & 32.9 & 32.6 & 31.6 & 26.9 & 28.2 & 31.2 & 31.1 \\
\hline $\begin{array}{l}\text { - growth } \\
\text { rate, } \%\end{array}$ & 100.0 & 100.0 & 99.1 & 96.0 & 81.8 & 85.7 & 94.8 & 94.5 \\
\hline $\mathrm{PL}$ & 32.1 & 32.8 & 32.8 & 32.9 & 33.1 & 32.9 & 33.7 & 32.9 \\
\hline $\begin{array}{l}\text { - growth } \\
\text { rate, } \%\end{array}$ & 100.0 & 102.0 & 102.2 & 102.5 & 103.1 & 102.5 & 105.0 & 102.5 \\
\hline EU & 26.3 & 26.6 & 26.6 & 26.1 & 24.3 & 25.6 & 24.8 & 24.5 \\
\hline EU ea & 26.6 & 26.8 & 27.0 & 26.5 & 24.5 & 26.3 & 25.0 & 24.8 \\
\hline \multicolumn{9}{|c|}{ 4. Value added in services, $\%$ of GDP } \\
\hline LT & 62.3 & 62.8 & 63.5 & 64.7 & 69.7 & 68.3 & 65.0 & 65.0 \\
\hline $\begin{array}{l}\text { - growth } \\
\text { rate, } \%\end{array}$ & 100.0 & 100.8 & 101.9 & 103.8 & 111.9 & 109.6 & 104.3 & 104.3 \\
\hline PL & 64.6 & 64.2 & 63.7 & 64.2 & 64.0 & 64.1 & 63.0 & 63.9 \\
\hline $\begin{array}{l}\text { - growth } \\
\text { rate, } \%\end{array}$ & 100.0 & 99.4 & 98.6 & 99.4 & 99.1 & 99.2 & 97.5 & 98.9 \\
\hline EU & 71.9 & 71.7 & 71.7 & 72.2 & 74.2 & 72.8 & 73.6 & 73.9 \\
\hline EUea & 71.5 & 71.4 & 71.2 & 71.8 & 73.9 & 72.0 & 73.3 & 73.5 \\
\hline
\end{tabular}

Note: LT -Lithuania; PL -Poland; EUea - EU euro area.

Source: author's calculations based on The World Bank Group Data; Statistical Office of Lithuania (2015); Central Statistical Office of Poland (2015).

The agriculture value added as per cent of GDP in the years 2005-2012 has decreased in Lithuania and Poland, by $16.7 \%$ and $3.0 \%$, accordingly. The agriculture value added as per cent of GDP in the EU and the EU euro zone was stable enough, but both in the EU and in the EU zone area it was approximately from 3 to 2.4 times less than it was in Lithuania, and about 2 times less than it was in Poland. On the other hand, agriculture is an im- 
portant strategic activity, which determines not only the production of food products and raw materials for other economic activities, but also a significant part of Lithuania's and Poland's exports.

Industry is very important in the structure of economic activity. Its growth very much depends on open economy and the amount of direct investments into the country from abroad. The industry value added as per cent of GDP has decreased in the years 2005-2012 in Lithuania - by 5.5\%; in the EU - by $5.8 \%$; in the EU euro area - by $6.8 \%$. The industry value added in Poland has increased by $2.5 \%$ during all analysed year. Structural changes linked to industrial value added are vital for the economic development of Poland.

The value added in the service sector in the structure of GDP of all analysed countries had the biggest share among other sectors in the countries. The value added in services in Lithuania, calculated as per cent of GDP, has increased mostly, by $4.3 \%$; in the EU - by $2.8 \%$; in the EU euro zone - by $2.8 \%$. The service sector value added in Poland, unlike Lithuania, has slightly decreased year by year, the reduction in comparison with the base year 2005 was $1.1 \%$.

Another important indicator - the level of domestic and foreign income, shown as GNIpc indicator is given in PPP (Table 2) terms in US dollars.

The GNIpc in Lithuania and in Poland the year 2005 was less than GNIpc of the EU; and the GNIpc in Lithuania was $53.8 \%$, and in Poland $51.1 \%$ from the level of the EU GNIpc. The GNIpc level in Lithuania in the year 2005 was $105.2 \%$ from the level of the GNIpc in Poland. The GNIpc in Lithuania has increased faster in comparison with Poland until the year 2008, then the growth was equal until the year 2011. The GNIpc in Lithuania in the year 2012 was $66.5 \%$, and in Poland $63.0 \%$ from the level of the GNIpc in the EU. It should be noted that the GNIpc in the EU euro area in the year 2005 was by $8.8 \%$ bigger than in the EU, and such trend continued until the year 2012 .

A significant factor of the economic development is the supply side factor, such as FDI. The development of different economic sectors depends from the flows of FDI. The FDIpc in Lithuania in the years 2005-2008 was bigger than in Poland. Economic downfall, which Poland did not experience, occurred in the year 2009. Poland became more attractive for investments from abroad, which is why FDIpc in the years 2009-2011 significantly increased in Poland in comparison with Lithuania. It is noted that FDIpc before the global financial crisis (in the year 2008) was bigger in the EU than in the EU euro zone. The FDIpc in the EU in the year 2009-2011 was bigger than in the EU. It is necessary to note that the FDIpc in Lithua- 
nia and Poland and in the EU and EU euro zone in the years 2005-2012 had diminishing tendency.

Table 2.The changes of GNIpc and economic development factors in the year2005-2012

\begin{tabular}{lcccccccc}
\hline & $\mathbf{2 0 0 5}$ & $\mathbf{2 0 0 6}$ & $\mathbf{2 0 0 7}$ & $\mathbf{2 0 0 8}$ & $\mathbf{2 0 0 9}$ & $\mathbf{2 0 1 0}$ & $\mathbf{2 0 1 1}$ & $\mathbf{2 0 1 2}$ \\
\hline LT & 14440 & 16430 & 18350 & 20010 & 18540 & 19470 & 21590 & 23080 \\
\hline PL & 13720 & 14930 & 16390 & 17930 & 18600 & 19910 & 21290 & 21830 \\
\hline EU & 26844 & 29096 & 30669 & 31908 & 31269 & 32001 & 33343 & 33376 \\
\hline EUea & 30187 & 32762 & 34537 & 35801 & 35188 & 36126 & 37620 & 37633 \\
\hline \multicolumn{7}{c}{ 2. FDIpc, USD } \\
\hline LT & 358.1 & 621.8 & 719.9 & 596.4 & 6.0 & 278.3 & 476.3 & 192.0 \\
\hline PL & 289.6 & 564.2 & 670.9 & 394.2 & 377.1 & 447.2 & 540.5 & 173.9 \\
\hline EU & 1513.9 & 1420.7 & 2097.6 & 1698.7 & 719.2 & 630.8 & 920.4 & 548.3 \\
\hline EUea & 1342.3 & 1309.5 & 1925.5 & 1308.4 & 1013.4 & 1495.0 & 1234.3 & 517.9 \\
\hline \multicolumn{7}{c}{3. Employed persons, millions } \\
\hline LT & 1.435 & 1.450 & 1.472 & 1.452 & 1.347 & 12.690 & 1.304 & 1.334 \\
\hline PL & 14.362 & 14.942 & 15.669 & 16.338 & 16.403 & 16.40 & 16.625 & 16.655 \\
\hline EU & 215.49 & 219.44 & 223.70 & 226.28 & 222.07 & 220.76 & 221.51 & 220.04 \\
\hline EUea & 140.59 & 143.09 & 146.02 & 147.52 & 144.70 & 143.85 & 144.30 & 143.02 \\
\hline
\end{tabular}

Note: LT -Lithuania; PL -Poland; EUea - EU euro area.

Source: author's calculations based on The World Bank Group Data; Statistical Office of Lithuania (2015); Central Statistical Office of Poland (2015).

The next factor of economic development is the level of employment. The number of employed in Poland increased by $16 \%$, in the EU - by 2.7 $\%$ and in the EU euro zone - by $1.7 \%$. The number of employed in Lithuania in years 2005-2008 increased by $2.5 \%$, but since the year 2009 it began to decline and in 2012, it did not reach the employment level of the year 2009.

\section{Economic Development Index and Its Structure}

The economic development index, according to the described method, is calculated and given in Table 3. The calculation shows that different countries achieved different situations. Economic growth in Lithuania slowed down a bit in the year 2008, and the downfall occurred in year 2009. Calculated economic development index in 2010 shows that the Lithuanian economy has recovered, but only slightly, after the economic downfall. The 
economic development index in the year 2012 exceeds by $2.2 \%$ its level in the base year 2005 .

Table 3. The changes of economic development index and its structure

\begin{tabular}{|c|c|c|c|c|c|c|c|c|}
\hline & 2005 & 2006 & 2007 & 2008 & 2009 & 2010 & 2011 & 2012 \\
\hline \multicolumn{9}{|c|}{ 1. GNIpc, $\%$} \\
\hline LT & 33.4 & 38.0 & 42.5 & 46.2 & 42.6 & 45.0 & 49.7 & 53.3 \\
\hline PL & 33.4 & 36.3 & 39.9 & 43.6 & 45.3 & 48.5 & 51.8 & 53.1 \\
\hline $\mathrm{EU}$ & 33.4 & 36.2 & 38.1 & 39.6 & 40.0 & 39.9 & 41.6 & 41.7 \\
\hline EUea & 33.4 & 36.2 & 38.2 & 39.6 & 38.9 & 40.0 & 41.6 & 41.6 \\
\hline \multicolumn{9}{|c|}{ 2. FDIpc, $\%$} \\
\hline LT & 33.3 & 57.8 & 66.9 & 55.6 & 0.6 & 25.9 & 44.3 & 17.9 \\
\hline PL & 33.3 & 64.9 & 77.1 & 45.3 & 43.4 & 51.4 & 62.2 & 20.0 \\
\hline EU & 33.3 & 31.2 & 46.1 & 37.4 & 15.8 & 13.9 & 20.2 & 12.1 \\
\hline EUea & 33.3 & 32.5 & 47.9 & 32.5 & 25.2 & 37.1 & 30.6 & 12.9 \\
\hline \multicolumn{9}{|c|}{ 3.Employment index, $\%$} \\
\hline LT & 33.3 & 33.6 & 34.1 & 33.7 & 31.2 & 29.4 & 30.2 & 31.0 \\
\hline PL & 33.3 & 34.6 & 36.4 & 37.9 & 38.0 & 38.0 & 38.6 & 38.6 \\
\hline EU & 33.3 & 33.9 & 34.5 & 34.9 & 34.3 & 34.1 & 34.2 & 34.2 \\
\hline EUea & 33.3 & 33.9 & 34.6 & 34.9 & 34.3 & 34.1 & 34.2 & 33.9 \\
\hline \multicolumn{9}{|c|}{ 4.Index of economic development, $\%$} \\
\hline LT & 100.0 & 132.1 & 143.5 & 135.4 & 74.4 & 100.3 & 124.2 & 102.2 \\
\hline PL & 100.0 & 135.8 & 153.3 & 126.8 & 126.7 & 137.9 & 152.6 & 111.7 \\
\hline EU & 100.0 & 101.3 & 118.7 & 111.9 & 90.1 & 87.9 & 96.0 & 88.0 \\
\hline EUea & 100.0 & 102.6 & 120.7 & 107.0 & 98.4 & 111.2 & 106.4 & 88.4 \\
\hline
\end{tabular}

Note: LT -Lithuania; PL -Poland; EUea - EU euro area.

Source: author's calculations based on The World Bank Group Data; Statistical Office of Lithuania, 2015; Central Statistical Office of Poland, 2015.

The economic development index of Poland in the year 2005-2012 was bigger than in the base year value of economic development index. In 2012 economic development index in Poland decreased to its lowest value $-111.7 \%$ during the whole period of 2005-2012.

The EU and the EU euro zone in the year 2012 did not achieve the economic development level of the year 2008, because this index was, accordingly, $88.0 \%$ and $88.4 \%$. This process was caused by the contraction of FDIpc in these countries. Lithuania and Poland have increased the level of the index in the year 2012, and this index was, accordingly, $102.1 \%$ and $111.7 \%$.

The analysis of the changes of economic development index in Lithuania and Poland as neighborhoods countries significantly differs. This difference is due to higher employment level in Poland. 


\section{Discussion}

Economic development is closely related with the current structure of economic activity. Some authors emphasize that nowadays economy is orientated to the services activity. During the whole analyzed period of the years 2005-2012 the value of the services in Lithuania grew. It did not decrease even during the financial crisis in Lithuania in the year 2009 and the value added increased by $4.3 \%$ during the period of the years 2005-2012.

In Poland the level of value added in services did not reach the previous year 2005 level. Therefore this raise a question about the effects of industry value added changes. In Poland it increased by $2.5 \%$ and in Lithuania - decreased by $5.4 \%$. It is important that index of economic development in Poland in the year 2012 was $111.7 \%$, and in Lithuania $-102.2 \%$ in the comparison with the year 2005 .

\section{Conclusions}

Different economic indicators characterize the economic development of a country. Scientific research show such indicators as GDP, GDPpc, GNI, GNIpc, HDI and others. In this research, economic development index was chosen, which was constructed from three macroeconomic indicators: GNIpc, FDIpc and E.

It is significant that the analyses of structural changes of economic development index allow to characterize the main problems of economics policy and show the most important problems, which are necessary to consider in decision making process and in creating of economic policy. The research listed the neighboring countries - Lithuania and Poland - according to the used method and determined the level of economic development. According to the used method, Poland is first and Lithuania is second.

The study showed that the growth of income in Lithuania slightly exceeded the growth of income in Poland in the period of the years 20052012. In the EU and the EU zone, the growth in the years 2005-2012 exceeded the year 2005 level, but was less than in Lithuania and Poland.

FDIpc in the year 2012 in comparison with the year 2005 were slightly smaller, especially in the EU and the EU euro zone. In Lithuania and Poland, the decrease of FDIpc was significantly less than in the EU and the EU euro zone. So the decrease of FDIpc in Lithuania and Poland in the year 2012 was smaller than in the EU and EU euro zone. 
Employment index in the year 2005-2012 was the smallest in Lithuania and in the year 2012 did not reach the level of the year 2005. In the year 2012, the EU and the EU euro zone only slightly exceeded the employment index of the year 2005. In 2012 Poland successfully went over the level of the year 2005 by $5.3 \%$.

The analysis shows that the biggest problem of Lithuania's economic development is the decreased level of employment and diminished level of FDIpc. Due to the same reasons - the decline of FDIpc during the analyzed period in comparison with the base year 2005 - the EU and EU euro zone economic development index was less than $100 \%$.

\section{References}

Blanchard, S., \& Hoarau, J. (2011). Optimizing the New Formulation of the United Nation's Human Development Index: An Empirical View from Data Envelopment Analysis. Economics Bulletin, 31(1).

Ciburiene, J. (2014). The Changes of Economic Development Index: The Baltic States in the Context of European Union. In Political Sciences, Law, Finance, Economics and Tourism. Conference Proceedings, Vol. IV. DOI: http://doi: 10.5593/SGEMSOCIAL2014/B24/S7.089.

Ciegis, R., Ramanauskiene, J., \& Simanskiene, L. (2010a). The Evaluation of Sustainable Development of Lithuania Region. Klaipeda: Klaipeda University Press.

Ciegis, R., Tamosiūnas, T., Ramanauskienè, J., \& Navickas, K. (2010b). Sustainable Industrial Development Zones Assessment. Siauliai: Siauliu University Press.

Krugman, P., \& Wells, R. (2006). Macroeconomics. USA: Worth Publishers.

Davies, A., \& Quinlivan, G. (2006). A Panel Data Analysis of the Impact of the Trade on Human Development. Journal of Socio-Economies, 35. DOI: http://doi:10.1016/j.socec.2005.11.048.

Dudzevičiūte, G. (2013). The Research of the Economic Structural Changes: Energy Consumption Aspect. Journal of Security and Sustainability Issues, 2(4). http://dx.doiorg/10.9770/jssi.2013.2.4(2).

European Commission Strategy (2010). A Strategy for Smart, Sustainable and Inclusive Growth. Europe 2020. COM. Retrieved form http://eurlex.europa.eu/LexUriServ/LexUriServ.do?uri=COM:2020:2020:FIN:EN:PDF.

Central Statistical Office of Poland. (2015). Retrieved from http://stat.gov.pl./en/.

Miškinis, V., Baublys, J., Lekavičius, V., \& Morkvėnas, A. (2013). New Changes in Lithuanian Energy Sector. Journal of Security and Sustainability Issues, 2(3). DOI: http://dx.doi.org/10.9770/jssi.2013.2.3(2).

Radovanovic, B. (2011). Human Development Index as a Measure of Human Development. Filozofija I Drustvo, 3. DOI: http://doi.10.2298/FID1103193R. 
Rende, S., \& Donduran, M. (2011). Neighborhoods in Development: Human Development Index and Self-Organizing Maps. Social Indicators Research. 110(2). DOI: http://doi.10.1007/s11205-011-9955-x.

Selim, J. (2015).The Human Development Index - What It Is and What It Is Not? Human Development Reparts. Latest News. UNDP. Retrieved from hdr.undp.org/en/hdi_what-it-is.

Shwab, K., \& Porter, M. E. (2006). The Global Competitiveness Report: 2006. Geneva: World Economic Forum.

Shwab, K. (2013). The Global Competitiveness Report: 2012-2013. Geneva: World Economic Forum.

Statistical Office of Lithuania (2015). Retrieved from www://www.stat.gov.lt.

Ul Hag, M. (1999). Reflections on Human Development. Oxford: Oxford University Press.

Commisssion on the Measurement of Economic Performance and Social Progress (2009). Report by the Commission on the Measurement of Economic Performance and Social Progress. Retrieved from http://www.stiglitz-senfitoussi.fr/documents/rapport_anglais.pdf (10.03.2015).

Wolff, H., Chlong, H., \& Aufshamm, M. (2011). Classification, Detection and Consequences of Data Error. Evidence from the Human Development Index. Economic Journal, 121(553). DOI: http://doi.111/j.1468-0297.2010.02408x.

The World Bank Group Data. World Bank Data. World Development Indicators. Retrieved from http://www.databank.worldbank.org/data/views/reports/ tablview.aspx.

Tvaronavičiene, M., \& Kalašinskaite, K. (2010). Weather Globalization in Form of FDI Enchances National Wealth: Empirical Evidence from Lithuania. Journal of Business Economics Management, 11(1). DOI: http://dx.doi.org/10.3846 /jbem.2010.01. 